\title{
PENDEKATAN ANALYTICAL HIERARCHY PROCESS (AHP) UNTUK PENENTUAN NILAI EKONOMI LAHAN
}

\author{
Vera Methalina Afma \\ Dosen Tetap Prodi Teknik Industri, Fakultas Teknik Universitas Riau Kepulauan
}

\begin{abstract}
ABSTRAK
Tanah atau lahan merupakan salah salah satu sumber daya yang mempunyai peranan strategis dalam pembangunan perkotaan. Perkembangan pembangunan kota yang semakin pesat dan tingginya laju pertumbuhan penduduk merupakan faktor pendorong meningkatnya kebutuhan tanah di perkotaan. Sementara itu, tanah yang tersedia di daerah perkotaan terbatas. Hal ini menimbulkan permasalahan tanah perkotaan, seperti peningkatan harga tanah yang tak terkendali akibat adanya konflik kepentingan. Kebutuhan tanah bagi industri dan berbagai kegiatan ekonomi bersaing dengan kebutuhan tanah bagi perumahan yang terus meningkat. Hal ini tentu saja akan mempengaruhi nilai ekonomis lahan.

Adapun tujuan dari penelitian ini adalah mengetahui faktor yang mempengaruhi nilai ekonomis lahan dan mengetahui maka nilai bobot dari masing-masing faktor. Dalam mengetahui faktor-faktor yang mempengaruhi nilai ekonomis ini dilakukan menggunakan kuesioner yang disebarkan kepada para masyarakat, yang kemudian dioleh dengan AHP (Analytical Hierarchy Prosess).

Hasil penelitian menyimpulkan faktor yang mempengaruhi nilai ekonomis lahan adalah peruntukan lahan, aksesibilitas dan jarak ke pusat kegiatan. Sedangkan nilai bobot masing-masing faktor adalah bobot peruntukan lahan 0,09, bobot faktor aksesibilitas sebesar 0,64, dan bobot faktor jarak sebesar 0,27.
\end{abstract}

Kata kunci : lahan, nilai ekonomis, AHP (Analytical Hierarchy Prosess)

\section{PENDAHULUAN}

Tanah atau lahan merupakan salah salah satu sumber daya yang mempunyai peranan strategis dalam pembangunan perkotaan. Perkembangan pembangunan kota yang semakin pesat dan tingginya laju pertumbuhan penduduk merupakan faktor pendorong meningkatnya kebutuhan tanah di perkotaan. Sementara itu, tanah yang tersedia di daerah perkotaan terbatas. Hal ini menimbulkan permasalahan tanah perkotaan, seperti peningkatan harga tanah yang tak terkendali akibat adanya konflik kepentingan. Kebutuhan tanah bagi industri dan berbagai kegiatan ekonomi bersaing dengan kebutuhan tanah bagi perumahan yang terus meningkat.

Informasi harga tanah yang akurat dan mutakhir diperlukan dalam pengendalian harga tanah yang senantiasa berubah akibat berbagai kepentingan dalam penggunaan tanah. Penentuan harga tanah perkotaan yang objektif dapat diperoleh dengan pembuatan metode yang representatif. Besar kecilnya harga ini akan mempengaruhi nilai ekonomis lahan. Oleh karena itu, diperlukan suatu penelitian untuk mengetahui faktor yang mempengaruhi nilai ekonomis lahan ini.

Tujuan dari penelitian ini adalah mengetahui faktor yang mempengaruhi nilai ekonomis lahan dan mengetahui maka nilai bobot dari masing-masing faktor. Sedangkan manfaat yang diharapkan dari penelitian ini adalah menjadi faktor pertimbangan bagi seseorang yang akan menjual tanah yang dimilikinya. 


\section{TEORI NILAI EKONOMI LAHAN}

Pendekatan dalam penentuan nilai sewa lahan dapat dilihat dari berbagai sudut pandang keilmuan.Dari sudut pandang ekonomi nilai sewa lahan adalah seberapa lahan tersebut mempunyai nilai produktifitas. Sudut pandang perencanaan wilayah dan kota memberikan nilai sewa lahan dipengaruhi oleh lokasi, aksesibilitas serta ketersediaan infrastruktur, sarana dan prasarana umum lainnya.

Nilai ekonomis lahan tercermin dari pola dan intensitas pemanfaatan lahan dipengaruhi beberapa faktor, yang dapat dikelompokan menjadi beberapa sistem (Chapin dalam Wibowo, 2002) yaitu :

1. Sistem aktivitas

Sistem aktivitas adalah cara manusia dan lembaga mengorganisasikan berbagai aktivitas dalam rangka memenuhi berbagai kebutuhan hidupnya dan berinteraksi satu dengan yang lain. Sistem aktivitas meliputi perumahan, industri dan jasa. Sistem aktivitas akan mempengaruhi harga pasar tanah. Harga pasar tanah ditentukan oleh jenis kegiatan yang ditempatkan di atasnya (sistem aktivitas). Secara teoritis, harga lahan di perkotaan sangat dipengaruhi oleh biaya transpor, dimana biaya ini merupakan biaya angkutan (travelling cost) ditambah dengan waktu perjalanan yang dinyatakan dengan uang (Wingo dalam Wibowo, 2002). Dengan harga lahan $=\mathrm{f}$ (transport cost), selanjutnya Wingo menyimpulkan bahwa :

- Semakin dekat dengan pusat kota, harga lahan semakin tinggi

- Semakin jauh dengan pusat kota, harga lahan semakin rendah

- Di daerah pinggiran perkotaan, harga lahan mendekati 0 (nol)

Sehingga dapat dibuat kurva sebagai berikut :

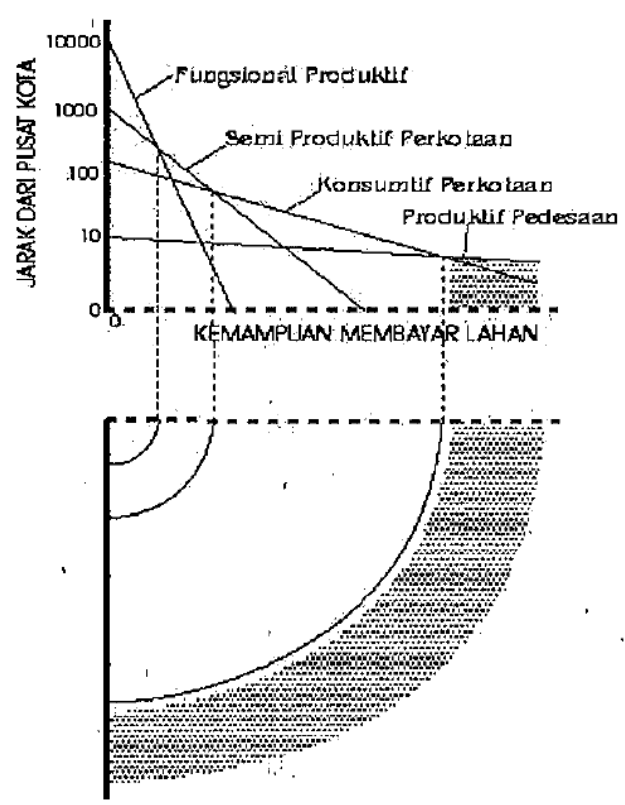

Gambar 1.

Hubungan Antara Jarak dari Pusat Kota dengan Harga Lahan dan Nilai Ekonomi Lahan (Sumber : Alonso dalam Brotosunaryodalam Wibowo, 2002)

Jika dikaitkan dengan pemanfaatan tanah kota, model di atas dapat membentuk concentric zone model of land use (Richardon dalam Wibowo, 2002) yang dapat digambarkan sebagai berikut : 


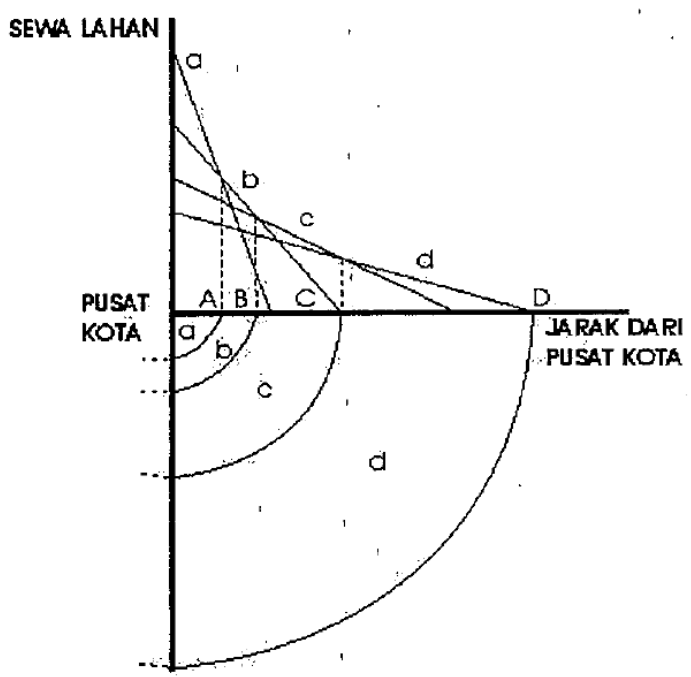

Gambar 2

Model Penggunaan Lahan yang Dipengaruhi Oleh Jarak dan Sewa Lahan (Sumber :Yeates dalam Brotosunaryo dalam Wibowo, 2002)

Oleh Von Thunnen, dengan menghubungkannya dengan aksesibilitas dan kemampuan membayar lahan, pemnafaatan lahan pada gambar di atas adalah (Yeates dalam Wibowo, 2002) :

$\mathrm{A}=$ dimanfaatkan untuk komersial dan perdagangan

$\mathrm{B}=$ dimanfaatkan untuk perumahan masyarakat berpenghasilan tinggi

$\mathrm{C}=$ dimanfaatkan untuk perumahan masyarakat berpenghasilan rendah

$\mathrm{D}=$ dimanfaatkan untuk pertanian

2. Sistem lingkungan

Luhst (1997) menyebutkan bahwa kualitas kehidupan yang berupa kenyamanan, keamanan dari suatu rumah tinggal sangat ditentukan oleh lokasinya, dalam arti daya tarik dari suatu lokasi ditentukan oleh dua hal yaitu lingkungan dan aksesibilitas. Lingkungan oleh Luhst didefenisikan sebagai suatu wilayah yang secara geografis dibatasi dengan batas nyata, dan biasanya dihuni oleh kelompok penduduk. Lingkungan mengandung unsur-unsur fisik dan sosial yang menimbulkan kegiatan dan kesibukan dalam kehidupan sehari-hari.Unsur-unsur tersebut berupa gedung-gedung sekolah, bangunan pertokoan, pasar, daerah terbuka untuk rekreasi, jalan mobil dan sebagainya. Aksesibilitas merupakan daya tarik suatu lokasi dikarenakan akan memperoleh kemudahan dalam pencapaiannya dari berbagai pusat kegiatan seperti pusat perdagangan, pusat pendidikan, daerah industri, jasa pelayanan perbankan, tempat rekreasi, pelayanan pemerintahan, jasa profesional dan bahkan merupakan perpaduan antara semua kegiatan tersebut. Penilaian dari aksesibilitas bisa berupa jarak dari Central Business Distrik atau CBD, kemudahan mendapat pelayanan dari transportasi umum yang menuju lokasi bersangkutan atau bisa juga dilihat dari lebar jalan yaitu semakin sempit lebar jalan suatu lahan, maka berarti aksesibilitas dari tempat yang bersangkutan kurang baik.

\section{KONSEP ANALYTICAL HIERARCHY PROCESS (AHP)}

Analytical Hierarchy Process (AHP) merupakan teknik untuk membantu menyelesaikan masalah yang besifat kompleks dengan cara mendekomposisikan masalah tersebut menjadi level-level hirarki (Sharma dkk, 2008). Dari tujuan yang bersifat umum 
dijabarkan dalam beberapa sub tujuan yang lebih rinci, yang menjelaskan apa yang dimaksud dalam tujuan pertama. Penjabaran ini dapat dilakukan terus hingga akhirnya diperoleh tujuan yang bersifat operasional. Pada hirarki terendah ini akan dilakukan proses evaluasi atas alternatif-alternatif yang menjadi ukuran pencapaian tujuan utama dan menentukan kriteria yang diukur.

Model AHP menggunakan aspek kualitatif, yaitu memakai pandangan manusia yang dianggap ahli dalam bidangnya sebagai input utamanya. Kriteria ahli pada hal ini merupakan orang yang paham akan permasalahan yang ada, sehingga dapat memberikan penilaian secara benar-benar obyektif. Selain itu, AHP juga menguji konsistensi penilaian. Bila terjadi penyimpangan yang terlalu jauh dari nilai konsisten sempurna maka penilaian perlu diperbaiki atau hirarki harus distruktur ulang.

Hirarki pada AHP terdiri dari tujuan secara keseluruhan, sekelompok pilihan untuk mencapai tujuan dan sekelompok kriteria (dan sub-kriteria) yang menghubungkan alternatif ke tujuan. Setiap kriteria dan alternatif dilakukan perbandingan berpasangan (pairwise comparison) untuk membandingkan setiap elemen dengan elemen lainnya pada setiap tingkat hirarki secara berpasangan. Elemen harus dapat melewati uji konsistensi dalam perbandingan berpasangan. Uji konsistensi ini dilakukan untuk mengetahui apakah pemikiran atau objek yang serupa dikelompokkan menurut persamaan dan apakah intensitas relasi antar gagasan atau antar obyek yang didasarkan pada suatu kriteria tertentu akan saling membenarkan secara logis. Adapun langkah-langkah metode AHP adalah sebagai berikut :

1) Menentukan jenis-jenis kriteria yang digunakan.

2) Menyusun kriteria-kriteria tersebut dalam bentuk matriks berpasangan.

$$
a_{i j}=\frac{w_{i}}{w_{j}}, \mathrm{i}, \mathrm{j}=1,2, \ldots, \mathrm{n}
$$

Dimana $\mathrm{n}$ menyatakan jumlah kriteria yang dibandingkan, wi bobot untuk kriteria ke-i dan aij adalah perbandingan bobot kriteria ke-i dan j. Dalam mengisi matriks perbandingan berpasangan, pengambil keputusan dibantu oleh skala yang terlihat pada tabel berikut (Saaty, 1990).

Tabel 1. Skala Penilaian Relatif

\begin{tabular}{|l|l|}
\hline $\begin{array}{l}\text { Tingkat Kepentingan } \\
1\end{array}$ & $\begin{array}{l}\text { Definisi } \\
\text { Kedua elemen sangat penting }\end{array}$ \\
\hline 3 & $\begin{array}{l}\text { Elemen yang satu sedikit lebih penting dibanding elemen } \\
\text { lainnya }\end{array}$ \\
\hline 5 & $\begin{array}{l}\text { Elemen yang satu esensial atau sangat penting dibanding } \\
\text { elemen lainnya }\end{array}$ \\
\hline 7 & $\begin{array}{l}\text { Elemen yang satu benar-benar lebih penting dari elemen } \\
\text { lainnya }\end{array}$ \\
\hline 9 & $\begin{array}{l}\text { Elemen yang satu mutlak lebih penting dibanding elemen } \\
\text { lainnya }\end{array}$ \\
\hline $2,4,6,8$ & Nilai tengah diantara dua penilaian berurutan \\
\hline
\end{tabular}

Skala tersebut menggambarkan relatif pentingnya suatu elemen atas elemen lainnya berkenaan dengan suatu sifat atau kriteria.

3) Menormalkan setiap kolom dengan cara membagi setiap nilai pada kolom ke-i dan baris ke-j dengan nilai terbesar pada kolom ke-i

$$
\hat{a}_{i j}=\frac{a_{i j}}{\max a_{i j}}
$$


4) Menjumlahkan nilai pada setiap kolom ke-i, yaitu

$\hat{a}_{i}=\sum_{i} \hat{a}_{i j}$

5) Menentukan bobot prioritas setiap kriteria ke-i dengan membagi setiap nilai dengan jumlah kriteria yang dibandingkan (n), yaitu

$$
\hat{w}_{i}=\frac{\hat{a}_{i}}{n}
$$

6) Menghitung Lamda max (eigen value) dengan rumus

$a \max =\frac{\sum a}{n}$

7) Menghitung Consistency Index (CI)

Penghitungan konsistensi adalah menghitung penyimpangan dari konsistensi nilai dari penyimpangan ini disebut Indeks Konsistensi dengan menggunakan persamaan :

$C I=\frac{a_{\max }-n}{n-1}$

dimana: $\quad a_{\max }=$ eigen value maksimum max a

$\mathrm{n} \quad=$ ukuran matriks

Consistency Index (CI) berupa matriks random dengan skala penilaian 1 sampai 9 beserta kebalikannya sebagai Random Index (RI). Berdasarkan perhitungan Saaty dengan menggunakan 500 sampel, jika "judgement" numerik diambil secara acak dari skala 1/9, 1/8, $1 / 7, \ldots, 1,2, \ldots, 9$, akan diperoleh rata-rata konsisten untuk matriks dengan ukuran yang berbeda, pada tabel berikut (Saaty, 1993).

Tabel 2. Nilai Indeks Random

\begin{tabular}{|c|c|c|c|c|c|c|c|c|c|c|}
\hline $\mathbf{N}$ & $\mathbf{1}$ & $\mathbf{2}$ & $\mathbf{3}$ & $\mathbf{4}$ & $\mathbf{5}$ & $\mathbf{6}$ & $\mathbf{7}$ & $\mathbf{8}$ & $\mathbf{9}$ & $\mathbf{1 0}$ \\
\hline $\mathbf{R I}$ & 0 & 0 & 0,58 & 0,9 & 1,12 & 1,24 & 1,32 & 1,41 & 1,45 & 1,49 \\
\hline
\end{tabular}

Perbandingan antara CI dan RI untuk suatu matriks didefinisikan sebagai Consistency Ratio (CR).

$C R=\frac{C I}{R I}$

Pada model AHP, matriks perbandingan dapat diterima jika nilai rasio konsistensi $(\mathrm{CR}) \leq 0,1$

8) Penghitungan rata-rata geometris

Langkah ini dilakukan untuk mencari nilai rata-rata perbandingan berpasangan yang diberikan oleh sebanyak $n$ pengambil keputusan dengan rumus sebagai berikut :

$\mathrm{a}_{\mathrm{i}}=\left(\mathrm{Z}_{1}, \mathrm{Z}_{2}, \ldots \mathrm{Z}_{\mathrm{n}}\right) 1 / \mathrm{n}$

dimana $a_{i} \quad$ : nilai rata-rata perbandingan berpasangan kriteria $i$ untuk $n$ partisipan (geometric mean)

$\mathrm{Z}_{\mathrm{i}} \quad$ : nilai rata-rata perbandingan antar kriteria untuk partisipan $\mathrm{i}$

$\mathrm{N} \quad$ : jumlah partisipan, i : $1,2,3, \ldots \mathrm{n}$

9) Penentuan bobot akhir

Merupakan kriteria atau sub-kriteria dengan nilai normalisasi yang terbesar.

\section{HASIL PENELITIAN}

Ada beberapa faktor yang mempengaruhi ekononis lahan yaitu sistem aktivitas dan sistem lingkungan. Sistem aktivitas meliputi peruntukan lahan tersebut seperti pemukiman, perdagangan dan jasa, pariwisata, industri, fasilitas sosial dan pendidikan. Sistem lingkungan 
artinya aksesibilitas dan jarak ke pusat kegiatan. Aksesibilitas terdiri dari beberapa kemungkinan yaitu MRT, tol, ROW 100 dan ROW 70. Jarak ke pusat kegiatan artinya jarak dari posisi lahan terhadap pusat pertumbuhan yamg dibagi ke dalam beberapa ring.

Perhitungan nilai bobot dari masing-masing kriteria dapat dilihat berikut ini.

\section{A. Perhitungan bobot untuk ketiga kriteria}

Tabel 3. Hasil Penilaian Narasumber Terhadap Ketiga Variabel

\begin{tabular}{|c|c|c|c|c|c|c|c|c|c|c|c|c|c|c|c|c|c|c|}
\hline \multirow{2}{*}{$\begin{array}{l}\text { KOLOM } \\
\text { KIRI }\end{array}$} & \multirow{2}{*}{$\begin{array}{c}\begin{array}{c}\text { Sama } \\
\text { penting }\end{array} \\
1 \\
\end{array}$} & \multicolumn{8}{|c|}{$\begin{array}{l}\text { Diisi jika faktor pada kolom kiri lebih } \\
\text { penting daripada faktor pada kolom }\end{array}$} & \multicolumn{8}{|c|}{$\begin{array}{l}\text { Diisi jika faktor pada kolom kanan } \\
\text { lebih penting daripada faktor pada }\end{array}$} & \multirow{2}{*}{$\begin{array}{l}\text { KOLOM } \\
\text { KANAN }\end{array}$} \\
\hline & & 2 & 3 & 4 & 5 & 6 & 7 & 8 & 9 & 2 & 3 & 4 & 5 & 6 & 7 & 8 & 9 & \\
\hline Peruntukan & & & & & & & & & & & & & $\mathrm{X}$ & & & & & Jarak \\
\hline Peruntukan & & & & & & & & & & & & & $X$ & & & & & Aksesibilitas \\
\hline Jarak & & & & & & & & & & & & $\mathrm{X}$ & & & & & & Aksesibilitas \\
\hline
\end{tabular}

Setelah hasil penilaian narasumber, hasil jawaban mereka dibuat dalam matrik perbandingannya, seperti terlihat pada tabel di bawah ini.

Tabel 4. Matrik Perbandingan Berpasangan Variabel

\begin{tabular}{|l|c|c|c|}
\hline \multicolumn{1}{|c|}{ Tipe Proses } & Peruntukan & Jarak & Aksesibilitas \\
\hline Peruntukan & 1,00 & 0,20 & 0,20 \\
\hline Jarak & 5,00 & 1,00 & 0,25 \\
\hline Aksesibilitas & 5,00 & 4,00 & 1,00 \\
\hline Jumlah & 11,00 & 5,20 & 1,45 \\
\hline
\end{tabular}

Setelah itu, dilakukan normalisasi matrik dan didapatkan nilai eigen value dari masingmasing komponen variabel terlihat dari table di bawah ini.

Tabel 5. Normalisasi Matrik Ketiga Variabel

\begin{tabular}{|l|c|c|c|c|}
\hline \multicolumn{1}{|c|}{ Tipe Proses } & Peruntukan & Jarak & Aksesibilitas & Eigen Vektor \\
\hline Peruntukan & 0,09 & 0,04 & 0,14 & 0,09 \\
\hline Jarak & 0,45 & 0,19 & 0,17 & 0,27 \\
\hline Aksesibilitas & 0,45 & 0,77 & 0,69 & 0,64 \\
\hline
\end{tabular}

Setelah itu, dilakukan perhitungan AHP untuk masing-masing variabel. Juga diawali dengan penilaian untuk masing-masing variabel.

B. Penentuan Bobot Variabel Jarak ke pusat-pusat kegiatan.

Jarak didekati dengan satuan radius terhadap pusat pertumbuhan pada masing-masing daerah. Dimana, semakin dekat ke pusat pertumbuhan maka semakin tinggi nilai pembobotannya. Atau semakin tinggi tingkat kepentingannya.

\section{Penentuan Bobot Variabel Aksesibilitas}

Faktor aksesibilitas dilihat berdasarkan dimensi dan fungsi jalan. Fator-faktor tersebut adalah rencana jaringan jalan dan dimensi jalan (MRT, TOL, ROW 100, ROW 70, ROW < 70)

Tabel 6. Hasil Penilaian Narasumber Terhadap Variabel Aksesibilitas 


\begin{tabular}{|c|c|c|c|c|c|c|c|c|c|c|c|c|c|c|c|c|c|c|}
\hline \multirow[t]{2}{*}{$\begin{array}{l}\text { KOLOM } \\
\text { KIRI }\end{array}$} & \multirow{2}{*}{$\begin{array}{c}\begin{array}{c}\text { Sama } \\
\text { penting }\end{array} \\
1 \\
\end{array}$} & \multicolumn{8}{|c|}{$\begin{array}{c}\text { Diisi jika faktor pada kolom kiri lebih } \\
\text { penting daripada faktor pada kolom kanan }\end{array}$} & \multicolumn{8}{|c|}{$\begin{array}{l}\text { Diisi jika faktor pada kolom kanan lebih } \\
\text { penting daripada faktor pada kolom kiri }\end{array}$} & \multirow[t]{2}{*}{$\begin{array}{l}\text { KOLOM } \\
\text { KANAN }\end{array}$} \\
\hline & & 2 & 3 & 4 & 5 & 6 & 7 & 8 & 9 & 2 & 3 & 4 & 5 & 6 & 7 & 8 & 9 & \\
\hline MRT & & & & $X$ & & & & & & & & & & & & & & TOL \\
\hline MRT & & & & & $X$ & & & & & & & & & & & & & ROW 100 \\
\hline MRT & & & & & & $\mathrm{X}$ & & & & & & & & & & & & ROW 70 \\
\hline MRT & & & & & & & $X$ & & & & & & & & & & & ROW $<70$ \\
\hline TOL & & & & $X$ & & & & & & & & & & & & & & ROW 100 \\
\hline TOL & & & & & $X$ & & & & & & & & & & & & & ROW 70 \\
\hline TOL & & & & & & $X$ & & & & & & & & & & & & ROW $<70$ \\
\hline ROW 100 & & & & $X$ & & & & & & & & & & & & & & ROW 70 \\
\hline ROW 100 & & & & & $X$ & & & & & & & & & & & & & ROW $<70$ \\
\hline ROW 70 & & & & $X$ & & & & & & & & & & & & & & ROW $<70$ \\
\hline
\end{tabular}

Tabel 7. Matrik Perbandingan Berpasangan Variabel Aksesibilitas

\begin{tabular}{|l|r|r|r|r|r|}
\hline TIPE PROSES & MRT & TOL & ROW 100 & ROW 70 & ROW $<70$ \\
\hline MRT & 1 & 4 & 5 & 6 & 7 \\
\hline TOL & 0,25 & 1 & 4 & 5 & 6 \\
\hline ROW 100 & 0,2 & 0,25 & 1 & 4 & 5 \\
\hline ROW 70 & 0,2 & 0,2 & 0,3 & 1 & 4,0 \\
\hline ROW $<70$ & 0,1 & 0,2 & 0,2 & 0,3 & 1 \\
\hline TOTAL & 1,8 & 5,6 & 10,5 & 16,3 & 23,0 \\
\hline
\end{tabular}

Tabel 8. Normalisasi Matrik Variabel Aksesibilitas

\begin{tabular}{|l|r|r|r|r|r|r|}
\hline TIPE PROSES & \multicolumn{1}{|l|}{ MRT } & TOL & ROW 100 & ROW 70 & ROW < 70 & EIGEN VALUE \\
\hline MRT & 0,57 & 0,71 & 0,48 & 0,37 & 0,30 & 0,49 \\
\hline TOL & 0,14 & 0,18 & 0,38 & 0,31 & 0,26 & 0,25 \\
\hline ROW 100 & 0,11 & 0,04 & 0,10 & 0,25 & 0,22 & 0,13 \\
\hline ROW 70 & 0,09 & 0,04 & 0,02 & 0,06 & 0,17 & 0,05 \\
\hline ROW $<70$ & 0,08 & 0,03 & 0,02 & 0,02 & 0,04 & 0,04 \\
\hline
\end{tabular}

Tabel 9. Nilai Bobot / Prioritas Variabel Aksesibilitas

\begin{tabular}{|l|c|}
\hline \multicolumn{1}{|c|}{ Tipe Proses } & Prioritas / Bobot \\
\hline MRT & 0,31 \\
\hline TOL & 0,16 \\
\hline ROW 100 & 0,08 \\
\hline ROW 70 & 0,03 \\
\hline ROW $<70$ & 0,02 \\
\hline
\end{tabular}

D. Peruntukkan Lahan

Peruntukkan lahan juga mempengaruhi nilai indeks zona lahan. Misalnya : kawasan pemukiman, kawasan industri, kawasan perdagangan dan jasa dan kawasan fasilitas umum mempunyai nilai yang berbeda.

Tabel 10. Hasil Penilaian Narasumber Terhadap Variabel Peruntukan Lahan 


\begin{tabular}{|c|c|c|c|c|c|c|c|c|c|c|c|c|c|c|c|c|c|c|}
\hline \multirow[t]{2}{*}{ KOLOM KIRI } & \multirow{2}{*}{\begin{tabular}{|c|}
$\begin{array}{c}\text { Sama } \\
\text { penting }\end{array}$ \\
1
\end{tabular}} & \multicolumn{8}{|c|}{$\begin{array}{l}\text { Diisi jika faktor pada kolom kiri } \\
\text { lebih penting daripada faktor } \\
\text { pada kolom kanan }\end{array}$} & \multicolumn{8}{|c|}{$\begin{array}{l}\text { Diisi jika faktor pada kolom } \\
\text { kanan lebih penting daripada } \\
\text { faktor pada kolom kiri }\end{array}$} & \multirow[t]{2}{*}{ KOLOM KANAN } \\
\hline & & 2 & 3 & 4 & 5 & 6 & 7 & 8 & 9 & 2 & 3 & 4 & 5 & 6 & 7 & 8 & 9 & \\
\hline Pemukiman & & & & & & & & & & $\mathrm{X}$ & & & & & & & & Perdagangan dan Jasa \\
\hline Pemukiman & & $\mathrm{X}$ & & & & & & & & & & & & & & & & Pariwisata \\
\hline Pemukiman & & $\mathrm{X}$ & & & & & & & & & & & & & & & & Industri \\
\hline Pemukiman & & & & & & & $\mathrm{X}$ & & & & & & & & & & & Fasos dan pendidikan \\
\hline Perdagangan dan Jasa & & $\mathrm{X}$ & & & & & & & & & & & & & & & & Pariwisata \\
\hline Perdagangan dan Jasa & & $\mathrm{X}$ & & & & & & & & & & & & & & & & Industri \\
\hline Perdagangan dan Jasa & & & & & & $\mathrm{X}$ & & & & & & & & & & & & Fasos dan pendidikan \\
\hline Pariwisata & & & $\mathrm{X}$ & & & & & & & & & & & & & & & Industri \\
\hline Pariwisata & & & & & & $\mathrm{X}$ & & & & & & & & & & & & Fasos dan pendidikan \\
\hline Industri & & & & & & $\mathrm{X}$ & & & & & & & & & & & & Fasos dan pendidikan \\
\hline
\end{tabular}

Tabel 11. Matrik Perbandingan Berpasangan Variabel Peruntukkan Lahan

\begin{tabular}{|l|c|c|c|c|c|}
\hline \multicolumn{1}{|c|}{ Tipe Proses } & Pemukiman & $\begin{array}{c}\text { Perdagangan } \\
\text { dan Jasa }\end{array}$ & Pariwisata & Industri & $\begin{array}{c}\text { Fasos dan } \\
\text { pendidikan }\end{array}$ \\
\hline Pemukiman & 1,00 & 0,20 & 2,00 & 2,00 & 7,00 \\
\hline Perdagangan dan Jasa & 5,00 & 1,00 & 2,00 & 2,00 & 6,00 \\
\hline Pariwisata & 0,50 & 0,50 & 1,00 & 3,00 & 6,00 \\
\hline Industri & 0,50 & 0,50 & 0,33 & 1,00 & 6,00 \\
\hline Fasos dan pendidikan & 0,14 & 0,17 & 0,17 & 6,00 & 1,00 \\
\hline Jumlah & 7,14 & 2,37 & 5,50 & 14,00 & 26,00 \\
\hline
\end{tabular}

Tabel 12. Normalisasi Matrik Variabel Peruntukkan Lahan

\begin{tabular}{|l|c|c|c|c|c|c|}
\hline \multicolumn{1}{|c|}{ Tipe Proses } & Pemukiman & $\begin{array}{c}\text { Perdagangan } \\
\text { dan Jasa }\end{array}$ & Pariwisata & Industri & $\begin{array}{c}\text { Fasos dan } \\
\text { pendidikan }\end{array}$ & Eigen Value \\
\hline Pemukiman & 0,14 & 0,08 & 0,36 & 0,14 & 0,27 & 0,20 \\
\hline Perdagangan dan Jasa & 0,70 & 0,42 & 0,36 & 0,14 & 0,23 & 0,37 \\
\hline Pariwisata & 0,07 & 0,21 & 0,18 & 0,21 & 0,23 & 0,18 \\
\hline Industri & 0,07 & 0,21 & 0,06 & 0,07 & 0,23 & 0,13 \\
\hline Fasos dan pendidikan & 0,02 & 0,07 & 0,03 & 0,43 & 0,04 & 0,12 \\
\hline
\end{tabular}

Tabel 13. Nilai Bobot / Prioritas Variabel Peruntukan

\begin{tabular}{|l|c|}
\hline \multicolumn{1}{|c|}{ Tipe Proses } & Prioritas / Bobot \\
\hline Pemukiman & 0,02 \\
\hline Perdagangan dan Jasa & 0,03 \\
\hline Pariwisata & 0,02 \\
\hline Industri & 0,011 \\
\hline Fasos dan pendidikan & 0,010 \\
\hline
\end{tabular}

Untuk peruntukan pemukiman, dibedakan atas 3 yaitu pemukiman kepadatan tinggi, sedang dan rendah, dan juga ditentukan bobot menggunakan AHP. Hasil AHP untuk ketiga komponen ini dapat dilihat berikut ini

Tabel 14. Penilaian Narasumber Terhadap Variabel Peruntukan Lahan Pemukiman 


\begin{tabular}{|c|c|c|c|c|c|c|c|c|c|c|c|c|c|c|c|c|c|c|}
\hline \multirow[t]{2}{*}{ KOLOM KIRI } & \multirow{2}{*}{$\begin{array}{c}\begin{array}{c}\text { Sama } \\
\text { penting }\end{array} \\
1 \\
\end{array}$} & \multicolumn{8}{|c|}{$\begin{array}{l}\text { Diisi jika faktor pada kolom kiri lebih } \\
\text { penting daripada faktor pada kolom }\end{array}$} & \multicolumn{8}{|c|}{$\begin{array}{l}\text { Diisi jika faktor pada kolom kanan } \\
\text { lebih penting daripada faktor pada }\end{array}$} & \multirow[t]{2}{*}{ KOLOM KANAN } \\
\hline & & 2 & 3 & 4 & 5 & 6 & 7 & 8 & 9 & 2 & 3 & 4 & 5 & 6 & 7 & 8 & 9 & \\
\hline Kepadatan tinggi & & & & & & & & & & & & & $\mathrm{X}$ & & & & & Kepadatan sedang \\
\hline Kepadatan tinggi & & & & & & & & & & & & & $\mathrm{X}$ & & & & & Kepadatan rendah \\
\hline Kepadatan sedang & & & & & & & & & & & & $\mathrm{X}$ & & & & & & Kepadatan rendah \\
\hline
\end{tabular}

Tabel 15. Matrik Perbandingan Berpasangan Variabel Peruntukkan Lahan Pemukiman

\begin{tabular}{|l|c|c|c|}
\hline \multicolumn{1}{|c|}{ Tipe Proses } & $\begin{array}{c}\text { Kepadatan } \\
\text { tinggi }\end{array}$ & $\begin{array}{c}\text { Kepadatan } \\
\text { sedang }\end{array}$ & $\begin{array}{c}\text { Kepadatan } \\
\text { rendah }\end{array}$ \\
\hline Kepadatan tinggi & 1,00 & 0,20 & 0,20 \\
\hline Kepadatan sedang & 5,00 & 1,00 & 0,25 \\
\hline Kepadatan rendah & 5,00 & 4,00 & 1,00 \\
\hline Jumlah & 11,00 & 5,20 & 1,45 \\
\hline
\end{tabular}

Tabel 16. Normalisasi Matrik Variabel Peruntukkan Lahan Pemukiman

\begin{tabular}{|l|c|c|c|c|}
\hline \multicolumn{1}{|c|}{ Tipe Proses } & $\begin{array}{c}\text { Kepadatan } \\
\text { tinggi }\end{array}$ & $\begin{array}{c}\text { Kepadatan } \\
\text { sedang }\end{array}$ & $\begin{array}{c}\text { Kepadatan } \\
\text { rendah }\end{array}$ & $\begin{array}{c}\text { Eigen } \\
\text { Value }\end{array}$ \\
\hline Kepadatan tinggi & 0,09 & 0,04 & 0,14 & 0,09 \\
\hline Kepadatan sedang & 0,45 & 0,19 & 0,17 & 0,27 \\
\hline Kepadatan rendah & 0,45 & 0,77 & 0,69 & 0,64 \\
\hline
\end{tabular}

Tabel 17. Nilai Bobot / Prioritas Variabel Peruntukan Pemukiman

\begin{tabular}{|l|c|}
\hline \multicolumn{1}{|c|}{ Tipe Proses } & Prioritas / Bobot \\
\hline Kepadatan tinggi & 0,002 \\
\hline Kepadatan sedang & 0,005 \\
\hline Kepadatan rendah & 0,011 \\
\hline
\end{tabular}

\section{KESIMPULAN}

Dari hasil penelitian, dapat disimpulkan bahwa :

1. Faktor yang mempengaruhi nilai ekonomis lahan adalah peruntukan lahan, aksesibilitas dan jarak ke pusat kegiatan.

2. Dari pendapat responden, maka nilai bobot masing-masing faktor ini adalah sebagai berikut bobot peruntukan lahan 0,09 , bobot faktor aksesibilitas sebesar 0,64 , dan bobot faktor jarak sebesar 0,27.

\section{DAFTAR PUSTAKA}

Badaruddin. 2012. Desain Pengukuran Kinerja Logistik Dengan Menggunakan Metode SCOR (Supply Chain Operations Reference) dan AHP (Analytic Hierarchy Process) (Studi Kasus Di PT. Infineon Batam). Yogyakarta : Universitas Islam Indonesia.

Helia, VN. 2011. Perancangan dan Pengukuran Kinerja Rantai Pasok di Instalasi Farmasi Rumah Sakit PKU Muhammadiyah Temanggung. Yogyakarta : Universitas Islam Indonesia. 
Luhst,K.M. 1997. Real Estate Valuation. Principles Aplication, USA.

Rosadi, dkk. 2009. Kajian Nilai Ekonomi Berdasarkan Tata Guna Lahan di Tiga Kecamatan Kabupaten Purwakarta. Simposium XII FSTPT, Universitas Kristen Petra Surabaya, 14 November 2009

Sari, dkk. 2010. Pemodelan Harga Tanah Perkotaan Menggunakan Metode Geostatistika. Jurnal Rekayasa Insitut Teknologi Nasional, LPPM Itenas No. 2 Vol. XIV

Wibowo, KW. 2002. Studi Mekanisme Penetapan Nilai Jual obyek Pajak Bumi Pada Pajak Bumi dan Bangunan Kota Banjarnegara. Tesis S2, Universitas Diponegoro, Semarang. 